
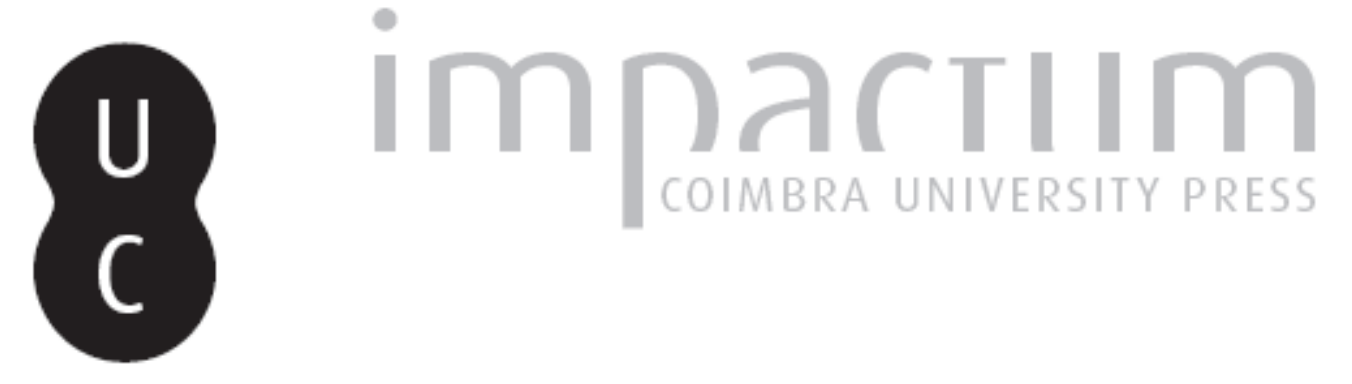

\title{
Conimbricae encomium de Inácio de Morais
}
Autor(es):
Ramalho, A. Costa
Publicado por: Associação Portuguesa de Estudos Clássicos; Instituto de Estudos Clássicos

URL persistente:

URI:http://hdl.handle.net/10316.2/30435

DOI:

DOI:http://dx.doi.org/10.14195/0872-2110_50_6

Accessed : $\quad$ 26-Apr-2023 09:58:48

A navegação consulta e descarregamento dos títulos inseridos nas Bibliotecas Digitais UC Digitalis, UC Pombalina e UC Impactum, pressupõem a aceitação plena e sem reservas dos Termos e Condições de Uso destas Bibliotecas Digitais, disponíveis em https://digitalis.uc.pt/pt-pt/termos.

Conforme exposto nos referidos Termos e Condições de Uso, o descarregamento de títulos de acesso restrito requer uma licença válida de autorização devendo o utilizador aceder ao(s) documento(s) a partir de um endereço de IP da instituição detentora da supramencionada licença.

Ao utilizador é apenas permitido o descarregamento para uso pessoal, pelo que o emprego do(s) título(s) descarregado(s) para outro fim, designadamente comercial, carece de autorização do respetivo autor ou editor da obra.

Na medida em que todas as obras da UC Digitalis se encontram protegidas pelo Código do Direito de Autor e Direitos Conexos e demais legislação aplicável, toda a cópia, parcial ou total, deste documento, nos casos em que é legalmente admitida, deverá conter ou fazer-se acompanhar por este aviso.

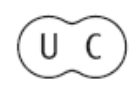




\section{Boletim de \\ Estudos Clássicos}

Associação Portuguesa de Estudos Clássicos Instituto de Estudos Clássicos

\section{Coimbra}

Dezembro de 2008 


\title{
CONIMBRICAE ENCOMIUM DE INÁCIO DE MORAIS
}

\author{
Antiquas reddit studiis Conimbrica Athenas: \\ Et docta praestat Pallade, et armigera. \\ Nam Lusitanos reges prima edidit olim, \\ Fortia qui in Mauros arma tulere truces. \\ Illa et totius fuit arx fortissima regni, \\ Constanti seruans integritate fidem. \\ Illam, dum Hispanas olim penetrauit in oras, \\ Condidit (ut fama est) Amphitryoniades.
}

Vivat, et in maius semper Conimbrica crescat,

Floreat et studiis, floreat atque opibus.

Hic mihi iucundam liceat traducere uitam:

Hic mea, cum moriar, molliter ossa cubent.

Os versos acima transcritos são o começo e o final do Conimbricae encomium publicado em 1554 e aqui citado segundo a edição do Prof. Mário Brandão, Conimbricae Encomium, Revisão e Prefácio, Coimbra, 1938.

Inácio de Morais foi uma das figuras mais coloridas do panorama humanístico português do seu tempo. O seu convívio com prestigiosos humanistas deixou marcos que ainda hoje são pontos de referência para os estudiosos do Humanismo Renascentista em Portugal.

Mencionarei apenas três desses marcos. É a Inácio de Morais que Pedro Sanches escreve a longa carta latina em verso, na qual aprecia sessenta poetas novilatinos portugueses, rica de comentários sobre a situação económica e social dos intelectuais na segunda metade do séc. XVI.

É também Morais o interlocutor mais livre de opiniões na Conuersio Miranda D. Aegidii Lusitani do seu amigo André de Resende. E finalmente a Morais pertence o panfleto In Quosdam Dialecticos et Grammaticos, pro Iure peritis no qual toma partido pelos juristas contra os gramáticos seus colegas de profissão, numa altura em que se tornara também jurista.

O Conimbricae Encomium exalta as novas construções que transformaram a bucólica Coimbra numa cidade universitária moderna e 
contém informações em primeira mão sobre a vida intelectual da urbe do Mondego.

Inácio de Morais faleceu em 1580 no Mosteiro de Alcobaça onde se acolhera.

\section{Bibliografia:}

Cf. o artigo de A. Costa Ramalho sobre I. M. em Enciclopédia Verbo Luso-Brasileira de Cultura, Edição Século XXI, vol. 20, p. 553-554 e a bibliografia aí citada. E ainda Aires Pereira do Couto, Inácio de Morais. Percurso biográfico e literário de um Humanista de Quinhentos, Lisboa, FCG/FCT, 2004; Virgínia Soares Pereira, André de Resende, Aegidius Scallabitanus (Um Diálogo sobre Fr. Gil de Santarém), Lisboa, FCG/FCT, 2000 .

A. COSTA RAMALHO 